\title{
Nigella seed oil as alternative to avilamycin antibiotic in broiler chicken diets
}

\author{
A.A. Saleh \\ Poultry Production Department, Faculty of Agriculture, Kafrelsheikh University, Egypt
}

(Received 9 October 2013; Accepted 15 June 2014; First published online 14 September 2014)

\author{
Copyright resides with the authors in terms of the Creative Commons Attribution 2.5 South African Licence. \\ See: http://creativecommons.org/licenses/by/2.5/za \\ Condition of use: The user may copy, distribute, transmit and adapt the work, but must recognise the authors and the South African \\ Journal of Animal Science.
}

\begin{abstract}
This study was conducted to study the effect of nigella seed oil as an alternative to the antibiotic, avilamycin, on growth, digestibility, muscle fatty acid profile and some physiological parameters in broiler chickens. Fifty four chicks at $15 \mathrm{~d}$ of age (average weight, $320 \pm 3 \mathrm{~g}$ ) were divided into a control group and two treatment groups $(n=18)$. The control group was fed a basal diet and the experimental treatment groups were fed the basal diet supplemented with avilamycin at a level of $0.001 \%$ or nigella seed oil at $1 \mathrm{~mL} / \mathrm{kg}$. Growth performance and breast muscle fatty acid profile were measured. Although feed intake was not affected, bodyweight gain was increased, and thus feed conversion ratio was improved by feeding nigella seed oil compared with the control and avilamycin groups. Plasma total cholesterol and low-density lipoprotein cholesterol (LDL-C) concentrations were higher, while, plasma high-density lipoprotein cholesterol (HDL-C) acid level was lower and polyunsaturated fatty acid levels were higher in the muscle fat of birds receiving nigella seed oil than those receiving the other treatments. It is concluded that feeding nigella seed oil as alternative to avilamycin antibiotic improved growth performance, modified the fatty acids profile in muscles and enhances plasma total cholesterol, LDL and HDL concentrations, and glutathione peroxidase (GSH-Px) activity.
\end{abstract}

Keywords: Avilamycin, black cumin, breast muscle, fatty acids, growth performance

\#E-mail address: ahmed.saleh1@agr.kfs.edu.eg

\section{Introduction}

Antibiotics used to be the principal growth-promoting substances in poultry production. Avilamycin is an antibiotic established for use as a growth promoter in poultry, especially broilers, to improve performance and feed efficiency (Valadirova et al., 1997; Saleh, 2012). At the same time, its use at sub-therapeutic levels in poultry diets decreases the microbial burden in the gastrointestinal tract and reduces susceptibility to disease. However, the use of avilamycin antibiotic, as a feed additive, is risky owing to cross-resistance among pathogens and residues in tissues (Schwarz et al., 2001). Therefore, the use of most antibiotic growth promoters has been banned in many countries, especially in the European Union since 2006 (Butaye et al., 2000). Consequently, the use of antibiotics in poultry diets was reduced, resulting in an intensified search for alternative natural growth promoters. Aromatic plants and essential oils extracted from these plants have become more important because of their antimicrobial actions (Wenk, 2003) and stimulating effects on the digestive systems of animals (Jamroz \& Kamel, 2002; Jang et al., 2004). As an aromatic plant, black cumin (Nigella sativa seed), is grown widely in different parts of the world, and its seeds have been used to promote health, especially in the Middle East and Southeast Asia. Nigella seeds have been widely used in traditional medicine as a diuretic and antihypertensive (Zaoui et al., 2000), digestive and appetite stimulant (Gilani et al., 2004), and an antidiarrheal (Gilani et al., 2001), anthelmintic (Chowdhury et al., 1998) and antibacterial agent (El-Kamali et al., 1998). Furthermore, other studies have shown nigella seed oil to be antidiabetic (Meral et al., 2001), anti-carcinogenic (Farah \& Begum, 2003), anti-inflammatory (Al-Ghamdi, 2001), spasmolytic and bronchodilatory (Gilani et al., 2001), and to possess antioxidant properties (Mansour et al., 2002). The current study was conducted to determine the usefulness of nigella seed oil in broiler nutrition as a natural growth-promoting substance to replace antibiotics, and to establish its effects on the performance, fatty acid profile and physiological status of broilers. 


\section{Materials and Methods}

This experiment was conducted in accordance with the guidelines of the Department of Poultry Production, Faculty of Agriculture, Kaferelsheikh University, Egypt. Fifty-four, one-day-old unsexed Lohman broiler chicks were housed in an electrically heated battery brooder, and provided with water and a commercial starter diet (a maize and soybean meal-based diet containing $230 \mathrm{~g}$ crude protein $/ \mathrm{kg}$ and 13.39 $\mathrm{MJ} \mathrm{ME} / \mathrm{kg}$ ) until 12 days of age. The chicks were housed in individual cages and fed the basal diet from 12 to 15 days of age. The composition of the basal diet (216.5 g crude protein $/ \mathrm{kg}$ and $13.17 \mathrm{MJ} \mathrm{ME} / \mathrm{kg}$ ) is shown in Table 1. The chicks were divided into three groups $(n=18)$. The control (consisting of the basal diet only), the avilamycin treatment, containing the basal diet and $0.001 \%$ avilamycin; and the nigella seed oil treatment, containing the basal diet plus $1 \mathrm{~mL} / \mathrm{kg}$ nigella seed oil. The birds were given the experimental diets from 15 to 37 days of age. The experiment was conducted in a temperature-controlled room with an 18 $\mathrm{h}$ light : $6 \mathrm{~h}$ dark cycle. Room temperature was kept at $28{ }^{\circ} \mathrm{C}$ with relative humidity from $50 \%$ to $70 \%$ throughout the experiment.

Table 1 Ingredient and nutrient composition of the basal diet

\begin{tabular}{ll}
\hline Ingredients & g/kg \\
\hline Maize & 565.2 \\
Soybean meal, 48\% & 300.0 \\
Corn gluten meal, 60\% & 60.0 \\
Premix & 3.0 \\
Soy oil & 40.0 \\
Dicalcium phosphate & 18.0 \\
Limestone & 10.0 \\
Salt & 3.8 \\
Calculated values** & \\
Crude protein, g/kg & 216.5 \\
Metabolizable energy, MJ/kg & 13.17 \\
Crude fibre, g/kg & 30.5 \\
Ether extract, g/kg & 66.0 \\
Calcium, g/kg & 8.9 \\
Phosphorus, g/kg & 4.8
\end{tabular}

*Each $3 \mathrm{~kg}$ of the vitamin/mineral premix contain: $6000000 \mathrm{IU}$ vitamin A; $900000 \mathrm{IU}$ vitamin $\mathrm{D}_{3} ; 40000 \mathrm{mg}$ vitamin E; $2000 \mathrm{mg}$ vitamin $\mathrm{K} ; 2000 \mathrm{mg}$ vitamin $\mathrm{B}_{1} ; 4000 \mathrm{mg}$ vitamin $\mathrm{B}_{2} ; 2000 \mathrm{mg}$ vitamin $\mathrm{B}_{6} ; 10 \mathrm{mg}$ vitamin $\mathrm{B}_{12} ; 50000 \mathrm{mg}$ niacin; 10000 mg pantothenic acid; 50 mg biotin; 3000 mg folic acid; 250000 mg choline; 50000 mg Zn; 8500 mg Mn; 50000 mg Fe; 50000 mg Cu; 200 mg l; 100 mg Se; 100 mg Co.

${ }^{* \star A}$ According to NRC (1994).

Bodyweight was recorded every three days and feed intake daily during the experimental period. At the end of this period, the birds were weighed and slaughtered, then dissected to measure the weights of the breast muscle, liver and abdominal fat. Blood samples were collected in heparinized test tubes and immediately centrifuged ( $3000 \mathrm{rpm}$ for $20 \mathrm{~min}$ ) to separate plasma. Plasma and meat samples were stored at $-30^{\circ} \mathrm{C}$ and $-10^{\circ} \mathrm{C}$, respectively, until further analysis.

Utilization coefficients of nutrients were calculated for dry matter, nitrogen and crude fat by analyses of the diets and collected excreta. On the last three days of the experiment, excreta were collected from each bird and weighed. Then the samples were dried in a drying oven at $60^{\circ} \mathrm{C}$ for $24 \mathrm{~h}$. The complete dried samples were homogenized, sampled, which were then finely ground to analyze for DM according to AOAC (1994). Crude protein content in diet and excreta was measured to determine nitrogen retention, using the Kjeldahl method (Randhir \& Pradhan, 1981) and crude fat was measured with Sukselt according to Bligh \& Dyer (1959). Calculations were as follows:

Nitrogen retention $(\%)=($ total nitrogen intake - total nitrogen excreted)/total nitrogen intake $X 100$. 
Concentrations in plasma of total cholesterol, HDL-C, LDL-C, glucose, total protein, albumin and globulin were measured colorimetrically using commercial kits (Diamond Diagnostics, Egypt) according to the procedures outlined by the manufacturer. Glutathione peroxidase (GSH-Px; EC 1.11.1.9) activity was determined by the method of Levander et al. (1983) and aspartate transaminase (AST; EC 2.6.1.1) and alanine transaminase (ALT; EC 2.6.1.2) activities were determined by the method of Reitman \& Frankel (1957).

Fatty acids were extracted from breast muscle tissue and analysed by using gas chromatography (GLC) according to the method described by Saleh (2013). Lipids were extracted from muscle by a mixture of chloroform-methanol $(2: 1)$ on a ratio of $(1: 5)$ in a separating funnel and shaken carefully for one hour. The extract was allowed to separate; the organic layer was taken, then passed through a glass funnel containing anhydrous sodium sulphate, and finally evaporated to near dryness by a stream of nitrogen. A sample of total lipids $\left(50 \mathrm{mg}\right.$ ) was transferred into a screw-cap vial, and $2 \mathrm{~mL}$ benzene and $10 \mathrm{~mL} 1 \% \mathrm{H}_{2} \mathrm{SO}_{4}$ in absolute methanol was added. The vial was covered under a stream of nitrogen before heating in an oven at $90{ }^{\circ} \mathrm{C}$ for $90 \mathrm{~min}$. Ten $\mathrm{mL}$ of distilled water were added to the cooled vial and the methyl esters in each vial were extracted. Ether extracts were combined and concentrated to their minimum volume by using a stream of nitrogen.

The analysis of fatty acids was carried out by gas liquid chromatography using a Shimadzu gas chromatograph GC-4 CM (PFE) equipped with a flame ionization detector (FID). A standard mixture of methyl esters was analysed under identical conditions prior to running the samples. The retention times of the unknown sample of methyl esters were compared with those of the standard. The concentration of methyl esters were calculated by the triangulation method.

Statistical analysis was as follows: The differences between the treatment groups and the control group were analysed with a general linear model using SPSS Statistics 17.0 (Statistical Packages for the Social Sciences, 2008). Tukeys multiple comparison test was used to separate means at a significance level of $P<0.05$.

\section{Results}

The effect of feeding avilamycin and nigella seed oil on live body weight, bodyweight gain, feed intake, feed conversion ratio, breast muscle weight, liver weight and abdominal fat weight is summarized in Table 2. Feeding nigella seed increased $(P<0.05)$ live body weight and bodyweight gain body weight gain, while feed intake was not significantly affected and thus the feed conversion ratio was improved compared with the control and avilamycin groups. Breast muscle weight was increased significantly by feeding nigella seed compared with the control and avilamycin groups. On the other hand, abdominal fat weight was decreased significantly while liver weight was not affected.

Table 2 Effect of feeding avilamycin and nigella seed oil on growth performance in broilers

\begin{tabular}{|c|c|c|c|}
\hline & Control & $\begin{array}{c}\text { Avilamycin } \\
0.001 \% \\
\end{array}$ & $\begin{array}{c}\text { Nigella seed oil } \\
1 \mathrm{~mL} / \mathrm{kg} \\
\end{array}$ \\
\hline $\begin{array}{l}\text { Initial body weight } \\
(\mathrm{BW}),(\mathrm{g})\end{array}$ & $320 \pm 3$ & $320 \pm 6$ & $320 \pm 5$ \\
\hline $\begin{array}{l}\text { Live weight at } \\
\text { slaughter, (g) }\end{array}$ & $1884^{\mathrm{b}} \pm 21$ & $1912^{b} \pm 23$ & $1995^{a} \pm 18$ \\
\hline BWG, (g/22 days) & $1564^{b} \pm 26$ & $1592^{\mathrm{ab}} \pm 30$ & $1675^{\mathrm{a}} \pm 18$ \\
\hline Feed intake, (FI) (g/22 days) & $2932 \pm 48$ & $2913 \pm 58$ & $2889 \pm 34$ \\
\hline Feed conversion ratio & $1.88^{\mathrm{a}} \pm 0.8$ & $1.83^{\mathrm{a}} \pm 1.1$ & $1.72^{b} \pm 0.9$ \\
\hline BMW, (g/100 g BW) & $23.8^{a} \pm 0.7$ & $24.8^{b} \pm 1.1$ & $27.3^{a} \pm 0.9$ \\
\hline Liver, (g/100 g BW) & $3.13 \pm 0.3$ & $3.29 \pm 0.2$ & $3.14 \pm 0.4$ \\
\hline Abdominal fat, (g/100 g BW) & $1.85^{\mathrm{a}} \pm 0.06$ & $1.3^{b} \pm 0.14$ & $0.98^{b} \pm 0.24$ \\
\hline
\end{tabular}


Nutrient utilization as influenced by avilamycin and nigella seed oil is presented in Table 3 . Dry matter utilization (DMU) and crude protein utilization (CPU) increased significantly when feeding nigella seed compared with the control and avilamycin groups, while crude fat utilization (CFU) was not affected.

Table 3 Effect of feeding avilamycin and nigella seed oil efficiency of nutrient utilization

\begin{tabular}{llcc}
\hline & Control & $\begin{array}{c}\text { Avilamycin } \\
\mathbf{0 . 0 0 1 \%}\end{array}$ & $\begin{array}{c}\text { Nigella seed oil } \\
\mathbf{1 ~} \mathbf{~ m L / k g}\end{array}$ \\
\hline DMU, (\%) & $68.4^{\mathrm{b}} \pm 5.1$ & $72.5^{\mathrm{a}} \pm 4.1$ & $76.7^{\mathrm{a}} \pm 4.2$ \\
$\mathrm{CPU},(\%)$ & $67.6^{\mathrm{b}} \pm 3.2$ & $72.4^{\mathrm{a}} \pm 4.2$ & $75.5^{\mathrm{a}} \pm 5.3$ \\
$\mathrm{CFU},(\%)$ & $55.7 \pm 5.3$ & $57.6 \pm 4.1$ & $58.8 \pm 4.2$
\end{tabular}

\footnotetext{
Values are expressed as means \pm standard error. Data were analysed by one-way analysis of variance and Tukey's multiple tests.

${ }^{\mathrm{a}-\mathrm{c}}$ Means within the same row with different superscripts differ $(P<0.05)$.

DMU: dry matter utilization; CPU: crude protein utilization; CFU: crude fat utilization.
}

The effects of feeding avilamycin and nigella seed oil on plasma traits (triglyceride, total cholesterol, HDL, LDL, glucose, total protein, albumin and globulin concentrations, and AST, ALT and GSH-Px activities) are summarized in Table 4. Plasma triglyceride, total cholesterol, LDL and glucose concentrations were significantly lower $(P \geq 0.05)$ through feeding of nigella seed oil compared with the control and avilamycin, while plasma HDL concentration and GSH-Px activity were higher $(P \geq 0.05)$. Plasma AST and ALT activities, as indices of liver functions, were lower, but not significantly so, by feeding nigella seed oil. Total protein, albumin and albumin/globulin concentrations increased through feeding nigella seed oil compared with the control and avilamycin.

Table 4 Effect of feeding avilamycin and nigella seed oil on some blood traits in broilers

\begin{tabular}{|c|c|c|c|}
\hline & Control & $\begin{array}{c}\text { Avilamycin } \\
0.001 \%\end{array}$ & $\begin{array}{c}\text { Nigella seed oil } \\
1 \mathrm{~mL} / \mathrm{kg} \\
\end{array}$ \\
\hline TG (mg/dL) & $26.1^{a} \pm 1.3$ & $23.4^{\mathrm{ab}} \pm 0.9$ & $20.1^{\mathrm{b}} \pm 1.3$ \\
\hline $\begin{array}{l}\text { TC } \\
(\mathrm{mg} / \mathrm{dL})\end{array}$ & $144.6^{\mathrm{a}} \pm 4.1$ & $138.8^{a} \pm 2.3$ & $124.7^{\mathrm{b}} \pm 3.1$ \\
\hline $\mathrm{HDL}(\mathrm{mg} / \mathrm{dL})$ & $72.6^{b} \pm 1.8$ & $80.5^{b} \pm 2.4$ & $92.9^{a} \pm 2.3$ \\
\hline LDL (mg/dL) & $66.8^{\mathrm{a}} \pm 4.8$ & $53.7^{\mathrm{a}} \pm 2.6$ & $27.8^{b} \pm 5.1$ \\
\hline AST (U/L) & $188 \pm 11$ & $185 \pm 13$ & $178 \pm 12$ \\
\hline ALT (U/L) & $26.8 \pm 3$ & $24 \pm 3$ & $21 \pm 2$ \\
\hline Glucose (mg/dL) & $189^{a} \pm 21$ & $185^{a} \pm 18$ & $163^{b} \pm 17$ \\
\hline GSH-Px (mg/dL) & $432^{b} \pm 41$ & $485^{b} \pm 38$ & $565^{a} \pm 37$ \\
\hline TP (mg/dL) & $3.04^{b} \pm 0.3$ & $3.81^{a b} \pm 0.2$ & $3.93^{\mathrm{a}} \pm 0.4$ \\
\hline Albumin (mg/dL) & $1.23^{b} \pm 0.05$ & $1.40^{\mathrm{ab}} \pm 0.07$ & $1.55^{a} \pm 0.03$ \\
\hline Globulin (mg/dL) & $1.80 \pm 0.12$ & $1.64 \pm 0.14$ & $1.66 \pm 0.15$ \\
\hline $\mathrm{A} / \mathrm{G}$ ratio & $0.68^{b} \pm 0.01$ & $0.85^{\mathrm{ab}} \pm 0.02$ & $0.93^{a} \pm 0.04$ \\
\hline
\end{tabular}


Data of fatty acids profile in breast muscle as affected by avilamycin and nigella seed oil are illustrated in Table 5. Myristic, palmitic and stearic acid concentrations as saturated fatty acids decreased significantly in the avilamycin and nigella seed oil treatment, and total saturated fatty acid concentrations decreased by feeding nigella seed oil. Oleic and eicosenoic acid concentrations, as monounsaturated fatty acids, were higher, and total monounsaturated fatty acids concentrations were significantly higher in both groups. Linoleic, linolenic and total polyunsaturated fatty acid concentrations increased $(P \geq 0.05)$ by feeding nigella seed and avilamycin compared with the control. The $\omega 6 / \omega 3$ ratio decreased, while the polyunsaturated/saturated fatty acid ratio increased by feeding nigella seed oil compared with the control and avilamycin groups.

Table 5 Effect of feeding avilamycin and nigella seed oil on fatty acid profile in breast muscle

\begin{tabular}{|c|c|c|c|}
\hline & Control & $\begin{array}{c}\text { Avilamycin } \\
0.001 \% \\
\end{array}$ & $\begin{array}{c}\text { Nigella seed oil } \\
1 \mathrm{~mL} / \mathrm{kg} \\
\end{array}$ \\
\hline \multicolumn{4}{|l|}{ Saturated fatty acid (SFA) } \\
\hline C14:0 Myristic acid & $0.24^{a} \pm 0.007$ & $0.13^{b} \pm 0.006$ & $0.14^{\mathrm{b}} \pm 0.006$ \\
\hline C16:0 Palmitic acid & $14.24^{\mathrm{a}} \pm 1.1$ & $9.12^{\mathrm{b}} \pm 0.96$ & $7.25^{c} \pm 0.69$ \\
\hline C18:0 Stearic acid & $2.59^{\mathrm{a}} \pm 0.14$ & $1.36^{\mathrm{b}} \pm 0.59$ & $1.94_{b} \pm 0.69$ \\
\hline SFA total & $17.87^{\mathrm{a}} \pm 2.9$ & $1.12^{\mathrm{b}} \pm 0.98$ & $8.9 \mathrm{c} \pm 1.01$ \\
\hline \multicolumn{4}{|l|}{ Monounsaturated fatty acid (MUFA) } \\
\hline C18:1, $\omega-9$ cis oleic acid & $18.02 \pm 1.4$ & $19.77 \pm 1.22$ & $21.88 \pm 1.29$ \\
\hline $\begin{array}{l}\text { C20:1, } \omega-9 \text { cis } 11-\text { eicosenoic } \\
\text { acid }\end{array}$ & $0.28^{\mathrm{c}} \pm 0.004$ & $0.38^{\mathrm{b}} \pm 0.003$ & $0.66^{a} \pm 0.005$ \\
\hline MUFAs total & $18.30^{\mathrm{b}} \pm 1.7$ & $20.15^{\mathrm{a}} \pm 1.03$ & $22.54^{\mathrm{a}} \pm 1.1$ \\
\hline \multicolumn{4}{|l|}{ Polyunsaturated fatty acid (PUFA) } \\
\hline C18:2, $\omega-6$ linoleic acid & $47.43^{b} \pm 3.3$ & $57.38^{\mathrm{a}} \pm 3.5$ & $57.50^{\mathrm{a}} \pm 4.6$ \\
\hline C18:3, $\omega-3 \alpha$-linolenic acid & $4.67^{\mathrm{b}} \pm 0.80$ & $5.99^{\mathrm{a}} \pm 0.78$ & $6.97^{\mathrm{a}} \pm 0.87$ \\
\hline PUFAs total & $52.10^{b} \pm 3.2$ & $63.37^{\mathrm{a}} \pm 4.2$ & $64.47^{\mathrm{a}} \pm 4.1$ \\
\hline$\omega 6 / \omega 3$ ratio & $10.15^{\mathrm{a}} \pm 0.94$ & $9.57^{b} \pm 0.5$ & $8.24^{b} \pm 0.7$ \\
\hline Poly/saturated relation & $2.91^{\mathrm{a}} \pm 0.24$ & $5.69^{b} \pm 0.7$ & $7.24^{\mathrm{a}} \pm 0.6$ \\
\hline
\end{tabular}

Values are expressed as means \pm standard error. Data were analyzed by one-way analysis of variance and Tukey's multiple tests.

${ }^{a-c}$ Means within the same row with different superscripts differ $(P<0.05)$.

*The analyses are expressed on a dry matter basis.

\section{Discussion}

The major objective of the present study was to establish whether growth performance, muscle fatty acids profile and physiological parameters of broilers could be modified by feeding nigella seed oil as an alternative to the antibiotics, avilamycin. Various researchers have reported that nigella seed had antimicrobial activity against Streptococcus mutans (Namba et al., 1985) and Micrococcus pyogenes var. aureus (Kapoor, 1990). The essential oil extracted from nigella seed showed antifungal activity against Aspergillus species and Curvularia lunata (Agarwal et al., 1979), as well as against the pathogenic yeast, Candida albicans (Hanafy \& Hatem, 1991). In addition, Rathee et al. (1982) reported that nigella seed oil has antibacterial and antifungal actions and showed protective action against hepatoxicity, which led to higher efficiency of nutrient utilization in the feed. Controlling the gut micro flora could positively affect broiler growth performance (Gunal et al., 2006). In the present study it was found that bodyweight gain and breast muscle weight were increased significantly in birds fed nigella seed oil, while feed intake was insignificantly decreased and feed conversion ratio was improved compared with the control and avilamycin groups. These results are in agreement with those of Hernandez et al. (2004) and Abu-Dieyeh \& Abu-Darwish (2008), who reported that nigella seed oil improved growth performance. Similarly, Denli et al. (2004) reported that supplementation with black cumin seed extract did not significantly affect the feed intake of quail. Al-Beitawi \& El-Ghousin (2008) found that inclusion of $1.5 \%$ crushed nigella sativa seeds in broiler rations improved 
growth and the feed conversion ratio. The improvement in bodyweight gain and feed conversion ratio could relate to increased feed utilization efficiency and altered carcass composition. Similarly, other studies reported that essential oils block the effect of pathogens in the digestive system (Alçiçek et al., 2003), and improve feed conversion ratio and carcass yield (Giannenas et al., 2003).

Increased dry matter and crude protein digestibilities in broilers on the nigella seed oil treatment in the present study may be because of enhanced enzymes activity caused by the seed oil. Jang et al. (2004) reported that supplementation with essential oil increased trypsin and pancreatic amylase activity. Similarly, Jamroz \& Kamel (2002) reported that supplementation with essential oil increased the digestion of protein, cellulose and fat in broilers. Wellenreiter et al. (1987) found that performance was enhanced by feeding avilamycin and that the mechanism revolves around a glucose sparing effect, a reduction in lactate production and increased volatile fatty acid production and absorption in the lower digestive tract of the broiler. In addition, Jamroz et al. (1995) demonstrated that avilamycin increases nitrogen retention and reduces nitrogen excretion in broilers, thus creating a "protein sparing" effect.

Dietary supplementation with nigella seed oil significantly decreased $(P \geq 0.05)$ plasma triglyceride, total cholesterol, glucose and LDL concentrations, while plasma HDL, total protein, albumin concentrations and GSH-Px activity were significantly increased. These are agreement with Aly et al. (2003), who reported that broiler chicks fed nigella seed had a lower $(P \geq 0.05)$ plasma cholesterol concentration than those fed the control diet. The significant reductions in triglycerides and cholesterol levels by feeding diets supplemented with nigella seed oil may be because of its high content of unsaturated fatty acids, particularly linoleic acid (Abdel-Aal \& Attia, 1993). Linoleic acid may stimulate cholesterol excretion into the intestine (Tollba \& Hassan, 2003). Nonetheless, the increase in total protein and albumin may be because of an immunostimulanting effect of nigella seed oil (Aqel, 1993). Nigella seed oil contains reasonable amounts of macroand micro-mineral elements that are involved in the growth process. They are essential for optimal performance and could enhance the immune system and increased total protein and albumin concentrations (William, 1997). The lowest activities for plasma ALT and AST were recorded for chicks fed diets supplemented with nigella seed oil. This indicates that the feeding of nigella seed oil diets to broiler chicks had a non-toxic effect on the liver and kidneys, and did not alter liver enzyme activity. This conforms with the results of El-Saleh et al. (2004), who found a decrease in AST and ALT activity from feeding broilers nigella seed. The increase in GSH-Px activity may be because nigella seed oil is known to possess strong antioxidant activities (El-Dakhakhny et al., 2002a; Mahmoud et al., 2002). On the other hand, Emadi \& Kermanshahi (2006) observed a significant increase in HDL cholesterol concentration and a decreased level of LDL cholesterol but a non significant effect on total triglycerides in male broiler chickens fed a diet containing avilamycin. The changes in the mean values of serum cholesterol and HDL in the birds fed avilamycin may be because of the possible mechanism of hypocholesterolaemic and hypolipidemic actions of garlic products, such as allicin, which suppresses the hepatic activities of lipogenic and cholesterogenic enzymes such as malic enzyme, fatty acid synthase, glucose-6-phosphatase dehydrogenase (Chi et al., 1982) and 3 hydroxyl 3 methyl-glutaryl-CoA (HMG-CoA) reductase (Qureshi et al., 1987).

Polyunsaturated fatty acid concentrations in the breast muscle were increased by feeding nigella seed oil, while saturated fatty acid concentrations decreased significantly. This effectiveness may be because of a combination of fatty acids ( $85 \%$ unsaturated fatty acids), volatile oils and trace elements (Cheikh et al., 2007). Abbas et al. (2012) found that the fatty acid patterns of nigella sativa seed oil were qualitatively similar to those of other plants; the essential fatty acid linoleic (52.6\%) being the major fatty acid, followed by oleic acid (23.5\%). Linolenic acid was detected in small quantities in samples. It was also noted that nigella sativa oil contained mainly unsaturated fatty acids (78.4\%), and only $21.6 \%$ saturated fatty acids. The major saturated fatty acid was palmitic $(16 \%)$. The most prominent feature of the fatty acid composition in nigella sativa seed oil was its high concentration of linoleic acid.

\section{Conclusion}

The present study shows that growth performance improved; the muscle lipid profile was modified and physiological parameters were enhanced by the addition of nigella seed oil as an alternative to the antibiotic, avilamycin, in broiler diets.

\section{Acknowledgements}

The author wishes to acknowledge the helpful suggestions of members of the Department of Poultry Production, Faculty of Agriculture, Kafrelsheikh University, Egypt. 


\section{References}

Abbas, A.M., Abu Sayeed, M., Alam, M.S., Yeasmin, M.S., Khan, A.M. \& Muhamad, I., 2012. Characteristics of oils and nutrient contents of nigella sativa linn and trigonella foenum-graecum seeds. Bull. Chem. Soc. Ethiop. 26, 55-64.

Abdel-Aal, E.S. \& Attia, R.S., 1993. Characterization of black Figure 2: Effect of Nigella sativa treatments and production interval on serum total lipids (mg/dl) levels, cumin (Nigella sativa): Chemical composition and lipids. Alex. Sci. Exch. J. 14, 467-481.

Abu-Dieyeh, Z.H.M. \& Abu-Darwish, M.S., 2008. Effect of feeding powdered black cumim seed (Nigella sativa L.) on growth performance of 4-8 week old broilers. J. Anim. Vet. Advan. 3, 286-290.

Agarwal, R., Kharya, M.D. \& Shrivastava, R., 1979. Pharmacological studies of essential oil and unsaponifiable matter of seeds of Nigella sativa. Indian J. Pharmacol. 41, 248. Abstr.

AL-Beitawi, N. \& El-Ghousein, S.S., 2008. Effect of feeding different levels of nigella sativa seeds (Black Cumin) on performance, blood constituents and carcass characteristics of broiler chicks. Int. J. Poult. Sci. 7, 715-721.

Alçiçek, A., Bozkurt, M. \& Çabuk, M., 2003. The effect of essential oil combination derived from selected herbs growing wild in Turkey on broiler performance. S. Afr. J. Anim. Sci. 33, 89-94.

Al-Ghamdi, M.S., 2001.The anti-inflammatory analgesic and antipyretic activity of Nigella sativa. J. Ethnopharmacol. 76, 45-48.

Aly, M., Shalash, S.M., Amer, M.I. \& Abdel-Mageed, M.A., 2003. Effect of substituting soybean meal by Nigella sativa meal on growth performance, carcass characteristics, blood constituents and sensory evaluation for broiler chicks. Mansoura. Uni. J. Agri. Sci. 28, 1759-1781.

Aqel, M.B., 1993. Effects of Nigella sativa seeds on intestinal smooth muscle. Int. J. Pharmacol. 31, 55-60.

Association of analytical communities, 1994. Association of official analytical chemists, "Official Methods of Analysis. $15^{\text {th }}$ ed. Published by the A.O.A.C. Washington, D.C., U.S.A.

Bligh, E.G. \& Dyer, W.J., 1959. Fat extraction (cited by Pearson's chemical analysis of foods). $8^{\text {th }}$ ed.

Butaye, P., Van Damme, K., Devriese, L.A., Lauwers, S. \& Haesebrouck, F., 2000. In Vitro susceptibility of Enterococcus faecium isolated from food to growth-promoting and therapeutic antibiotics. Int. J. Food Microbiol. 54, 181-187.

Cheikh, R.S., Besbes, S., Hentati, B., Blecker, C., Deroanne, C. \& Attia, H., 2007. Nigella sativa L. chemical composition and physicochemical characteristics of lipid fraction. Food Chemist. 101, 673-681.

Chi, M.S., Koh, E.T. \& Stewart, T.J., 1982. Effects of garlic on lipid metabolism in rats fed cholesterol or lard. J. Nutr. 112, 241-248.

Chowdhury, A.A., Islam, A., Rashid, A. \& Ferdous, A., 1998. Therapeutic potential of the volatile oil of Nigella sativa seeds in monkey model with experimental shigellosis. Phytother. Res. 12, 361-363.

Denli, M., Okan, F. \& Uluocak, A.N., 2004. Effect of dietary black seed (Nigella sativa L.) extract supplementation on laying performance and egg quality of quail (Coturnix coturnix japonica). J. Appl. Anim. Res. 26, 73-76.

El-Dakhakhny, M., Mady, N.J., Lembert, N. \& Ammon, H.P., 2002. Nigella sativa oil, nigellone and derived thymoquinone inhibit synthesis of 5-lipoxygenase products in polymorphonuclear leukocytes from rats. J. Ethnopharmacol. 81, 161-164.

El-Kamali, H.H., Ahmad, A.H., Mohammad, A.S., Yahia, A.M., El-Tayeb, I. \& Ali, A.A., 1998. Antibacterial properties of essential oils from Nigella sativa seeds etc. Fitoterapia 69, 77-78.

El-Saleh, S.C., Al-Sagair, O.A. \& Al-Khalaf, M.I., 2004. Thymoquinone and Nigella sativa oil protection against methionine-induced hyperhomocysteinemia in rats. Int. J. Cardiol. 93, 19-23.

Emadi, M. \& Kermanshahi, H., 2006. Effect of turmeric rhizome powder on performance and carcass characteristics of broiler chickens. Int. J. Poult. Sci. 5, 1069-1072.

Farah, I.O. \& Begum, R.A., 2003. Effect of Nigella sativa and oxidative stress on the survival pattern of MCF-7 breast cancer cells. Biomed. Sci. Instrum. 39, 359-364.

Giannenas, I., Florou-Paneri, P., Papazahariadou, M., Christaki, E., Botsoglou, N.A. \& Spais, A.B., 2003. Effect of dietary supplementation with oregano essential oil on performance of broilers after experimental infect ion with Eimeria tenella. Archiv. Für. Tierernährung 57, 99-106.

Gilani, A.H., Aziz, N., Khurram, I.M., Chaudhary, K.S. \& Iqbal, A., 2001. Bronchodilator, spasmolytic and calcium antagonist activities of Nigella sativa seeds (Kalonji): a traditional herbal product with multiple medicinal uses. J. Pak. Med. Assoc. 51, 115-120.

Gilani, A.H., Jabeen, Q. \& Khan, M.U., 2004. A Review of medicinal uses and pharmacological activities of Nigella sativa. J. Biological. Sci. 7, 441-451.

Gunal, M., Yayli, G., Kaya, O., Karahan, N. \& Sulak, O., 2006. The effects of antibiotic growth promoter, probiotic or organic acid supplementation on performance, intestinal microflora and tissue of broilers. Int. J. Poult. Sci. 5, 149-155. 
Hanafy, M.S. \& Hatem, M.E., 1991. Studies on the antimicrobial activity of Nigella sativa seed (Black cumin). J. Ethnopharmacol. 34, 275-278.

Hernandez, F., Madrid, J., Garcia, V., Orengo, J. \& Megias, M.D., 2004. Influence of two plant extract on broiler performance, digestibility, and digestive organ size. Poult. Sci. 83, 169-174.

Jamroz, D. \& Kamel, C., 2002. Plant extracts enhance broiler performance. In: Non-ruminant nutrition: Antimicrobial agents and plant extracts on immunity, health and performance. J. Anim. Sci. 80, (Suppl. 1), 41.

Jamroz, D., Kirchgessner, M. \& Wiliczkiewicz, J.O., 1995. Effect of application of avilamycin (Maxus) and different levels of crude protein in concentrate mixtures on the nitrogen excretion and retention and on the apparent digestibility of amino acids in broiler chickens. Arch. Geflugelk. 59, 152-157.

Jang, I.S., Ko, Y.H., Yang, H.Y., Ha, J.S., Kim, J.Y., Kim, J.Y., Kang, S.Y., Yoo, D.H., Na, S.D., Kim, D.H. \& Lee, C.Y., 2004. Influence of essential oil components on growth performance and the functional activity of the pancreas and small intestine in broiler chickens. Asian-Austral. J. Anim. Sci. 17, 394-400.

Kapoor, L.D., 1990. Handbook of Ayurvedic Medicinal Plants. CRC Press, Inc. Boca Raton, Florida, USA.

Levander, O.A., Deloach, D.P., Morris, V.C. \& Moser, P.B., 1983. Platelet glutathione peroxidase activity as an index of selenium status in rats. J. Nutr. 113, 55-63.

Mahmoud, M.R., El-Abhar, H.S. \& Saleh, S., 2002. The effect of Nigella sativa oil against the liverdamage induced by Schistosoma mansoni infection in mice. J. Ethnopharmacol. 79, 1-11.

Mansour, M.A., Nagi, M.N., El-Khatib, A.S. \& Al-Bekairi, A.M., 2002. Effects of thymoquinone on antioxidant enzyme activities, lipid peroxidation and DT-diaphorase in different tissues of mice: a possible mechanism of action. Cell Biochem. Funct. 20,143-151.

Meral, I., Yener, Z., Kahraman, T. \& Mert, N., 2001. Effect of Nigella sativa on glucose concentration, lipid peroxidation, anti-oxidant defense system and liver damage in experimentally-induced diabetic rabbits. J. Vet. Med. A, Physiology, Pathology, Clinical Medicine 48, 593-599.

Namba, T., Tsunezuka, M., Saito, K., Kakiuchi, N., Hattori, M., Dissanayake, D.B. \& Pilapitiya, U., 1985. Studies on dental caries prevention by traditional medicines, screening of Ayuruedic medicines for anti-plaque action. Japanese J. Phramacog. 39, 146-153.

Qureshi, A.A., Crenshaw, T.D., Abuiremeileh, N., Peterson, D.M. \& Elson, C.E., 1987. Influence of minor plant constituents on porcine hepatic lipid metabolism: Impact on serum lipid. Atherosclerosis 64, 109-115.

Randhir, S. \& Pradhan, K., 1981. Forage Evaluation. First published, Printox, New Dalhi, Dhawan Printing Works.

Rathee, P.S., Mishra, S.H. \& Kaushal, R., 1982. Antimicrobial activity of essential oil, fixed oil and unsaponifiable matter of Nigella sativa L. Indian J. Pharm. Sci. 44, 8-10.

Reitman, S. \& Frankel, S., 1957. A colorimetric method for deterxmination of serum glutamic oxaloacetic and glutamic pyruvic transaminase. Am. J. Path. 26, 1-13.

Saleh, A.A., 2012. The effect of feeding aspergillus oryzae on growth performance, carcass parameters and some biochemical traits of broilers. Egypt. Poult. Sci. 32, 749-761.

Saleh, A.A., 2013. Effects of fish oil on the production performances, polyunsaturated fatty acids and cholesterol levels of yolk in hens. Emir. J. Food Agric. 25, 605-612.

Schwarz, S., Kehrenberg, C. \& Walsh, T.R., 2001. Use of antimicrobial agents in veterinary medicine and food animal production. J. Antimicrobial Agents 17, 431-437.

Tollba, A.H. \& Hassan, M.H., 2003. Using some natural additives to improve physiological and productive performance of broiler chicks under high temperature conditions. 2-Black cumin (Nigella sativa) or garlic (Allium sativum). Egypt. Poult. Sci. 23, 327-340.

Valadirova, L., Sourdjiisda, S. \& Dilow, T., 1997. Nutritive effect of avilamycin supplementation to chicken broiler mixes. Zhivotnov'Dni. Nauki. 34, 49-52.

Wellenreiter, R.H. \& Tonkinson, L.V., 1987. Avilamycin: A new growth promotant for broiler chickens. Proc. 10th Latin Am. Poultry Congress.

Wenk, C., 2003. Herbs and botanicals as feed additives in monogastric animals. Asian-Austral. J. Anim. Sci. $16,282-289$.

William, M.D., 1997. Endocrine glands. In: Ducks. Physiology of Domestic Animals. Ed: Swenson, J., 9th ed., Cornell Univ. Press. Ithaca and London.

Zaoui, A., Cherrah, Y., Lacaille-Dubois, M.A., Settaf, A., Amarouch, H. \& Hasar, M., 2000. Diuretic and hypotensive effects of Nigella sativa in the spontaneously hypertensive rat. Thérapie 55, 379-382. 